\author{
MARCIN MAZUR \\ Biuro Rzecznika Praw Obywatelskich \\ marcinmazur1@op.pl
}

\title{
Zatrudnienie osób odbywających karę pozbawienia wolności w działaniach Rzecznika Praw Obywatelskich
}

\section{Employment of persons serving prison sentences in the activities of the Ombudsman}

Streszczenie. W niniejszym artykule autor przedstawia w porządku chronologicznym działania, jakie podejmowali kolejni Rzecznicy Praw Obywatelskich w kwestii zatrudnienia osób pozbawionych wolności. Wskazano w nim, iż zagadnieniem, które ulegało już kilkukrotnym zmianom, jest poziom wynagrodzenia za pracę więźniów. Autor przedstawia szereg działań Rzecznika Praw Obywatelskich, które mają na celu ochronę praw więźniów do godziwego wynagrodzenia. Jednocześnie autor sugeruje, iż obecne rozwiązanie legislacyjne nie wpływa pozytywnie na poziom zatrudnienia i powinno być przygotowane nowe, w którym ustawodawca w większym stopniu odczyta zapatrywanie Trybunału Konstytucyjnego wyrażone w wyroku z dnia 23 lutego 2010 r. (P 20/09).

Słowa kluczowe: Rzecznik Praw Obywatelskich; zatrudnienie; osoby pozbawione wolności; wynagrodzenie minimalne.

\begin{abstract}
In this article, the author presents in chronological order actions which the succesive Ombudsmen undertook on the issue of persons deprived of liberty. In it it's pointed out that the issue which has been changed on several ocasions, is the renumeration for prisoners work. The author presents a series of actions of the Ombudsman, which are designed to protect the rights of prisoners to equitable renumeration. At the same time the author suggests that the current legislative solution has no positive effect on the employment and a new measure should be prepared, in which the legislator will more closely read the Constitutional Courts point of view expressed in its judgment of 23 February 2010 (P 20/09).
\end{abstract}

Keywords: The Ombudsman; employment; persons deprived of liberty; the minimum wage.

\section{Wprowadzenie}

Rzecznik Praw Obywatelskich (dalej: RPO lub Rzecznik) stale interesuje się sytuacją osób zatrudnionych przebywających w jednostkach penitencjarnych. Informacje i skargi w tej mierze Rzecznik otrzymuje od osób pozbawionych wolności we wnioskach kierowanych do RPO, jak również podczas wizytacji prewencyjnych prowadzonych w ramach Krajowego Mechanizmu Prewencji ${ }^{1}$. Trzeba wskazać, iż w myśl art. 1 ust. 4 ustawy z dnia 15 lipca

\footnotetext{
${ }^{1}$ Szerzej na temat Krajowego Mechanizmu Prewencji i jego działan, zob. https://www.rpo.gov.pl/pl/krajowymechanizm-prewencji [dostęp: 3 października 2015 r.].
} 
1987 r. o Rzeczniku Praw Obywatelskich² Rzecznik wykonuje funkcje organu wizytującego do spraw zapobiegania torturom i innemu okrutnemu, nieludzkiemu lub poniżającemu traktowaniu albo karaniu (krajowy mechanizm prewencji) w rozumieniu Protokołu fakultatywnego do Konwencji w sprawie zakazu stosowania tortur oraz innego okrutnego, nieludzkiego lub poniżającego traktowania albo karania, przyjętego przez Zgromadzenie Ogólne Narodów Zjednoczonych w Nowym Jorku dnia 18 grudnia 2002 r. (Dz. U. z 2007 r. Nr 30, poz. 192).

Działania RPO w kwestii zatrudnienia skazanych były podejmowane od wielu lat ${ }^{3}$. W niniejszym artykule skupię się jedynie na kilku działaniach, jednakże - w mojej ocenie niezmiernie istotnych.

\section{Wniosek RPO do Trybunału Konstytucyjnego z dnia 28 marca 1996 r.}

Zanim zostanie omówiony wniosek Rzecznika do Trybunału Konstytucyjnego (dalej TK lub Trybunał) krótki rys historyczny, jak doszło do jego skierowania. Po zmianie ustroju na demokratyczny, zmianie uległo również określenie zasady wynagradzania za pracę skazanych. W myśl art. 49 § 3 ustawy z dnia 19 kwietnia 1969 r. Kodeks karny wykonawczy ${ }^{4}$ (dalej: k.k.w. z 1969 r.) należność skazanego za pracę ustala się według zasad wynagradzania pracowników za pracę tego rodzaju, którą wykonuje skazany ${ }^{5}$. Wskutek zmian gospodarczych w kraju, następowało stałe zmniejszenie się osób pracujących odpłatnie, także wśród skazanych $^{6}$. Było to spowodowane również ogólnym wzrostem bezrobocia w pierwszych latach transformacji ustrojowej. W tej sytuacji zdecydowano się na znacząca zmianę w systemie zatrudnienia skazanych. Ustawą z dnia 12 lipca 1995 r. o zmianie Kodeksu karnego, Kodeksu karnego wykonawczego oraz o podwyższeniu dolnych i górnych granic grzywien i nawiązek w prawie karnym ${ }^{7}$ (art. 2 pkt 9 lit. a) z dniem 20 listopada 1995 r. dokonano zmiany art. 49 § 3 k.k.w z 1969 r. który otrzymał brzmienie: należność skazanego

\footnotetext{
${ }^{2}$ Tekst jedn. Dz. U. z 2014 r. poz. 1648, ze zm.

${ }^{3}$ Zob. M. Bramska, Zatrudnienie (w:) Stan i węzłowe problemy polskiego więziennictwa, red. J. Malec, RPOMat. Nr 28, Warszawa 1995, s. 262-288; T. Bulenda, R. Musidłowski, J. Zagórski, Konstytucyjne wolności i prawa socjalne osób uwięzionych $i$ ich urzeczywistnianie (w:) Godność człowieka a prawa ekonomiczne i socjalne. Księga jubileuszowa wydana w piętnasta rocznice ustanowienia Rzecznika Praw Obywatelskich, Warszawa 2003, s. 223-225.

${ }^{4}$ Dz. U. Nr 13, poz. 98, ze zm.

${ }^{5}$ Brzmienie cytowane nadane zostało przez art. 1 pkt 9 ustawy z dnia 23 lutego 1990 r. o zmianie Kodeksu karnego wykonawczego (Dz. U. Nr 14, poz.85) z dniem 28 marca 1990 r.

${ }^{6}$ Tabela obrazująca powszechność zatrudnienia skazanych i ukaranych w latach 1990-1997 r., zob. T. Kalisz, A. Kwieciński, Zmiany w zakresie odptatności za pracę skazanych odbywających karę pozbawienia wolności. Rozważania na tle orzecznictwa Trybunatu Konstytucyjnego (w:) Zmiany w prawie karnym wykonawczym w latach 2009-2014, red. A. Kwieciński, Warszawa 2014, s. 18-19.

${ }^{7}$ Dz. U. Nr 95, poz. 475.
} 
za pracę ustala się według zasad wynagradzania pracowników za pracę tego rodzaju, którą wykonuje skazany, chyba że skazany wyrazi zgodę na niższe wynagrodzenie.

Ta nowelizacja stała się przyczynkiem do skierowania przez RPO wniosku do Trybunału Konstytucyjnego z dnia 28 marca 1996 r. ${ }^{8}$. Rzecznik wniósł o wydanie orzeczenia stwierdzającego, że przepis art. $49 \S 3$ Kodeksu karnego wykonawczego w brzmieniu nadanym przez art. 2 pkt 9 lit. a) ustawy z dnia 12 lipca 1995 r. o zmianie Kodeksu karnego, Kodeksu karnego wykonawczego oraz o podwyższeniu dolnych i górnych granic grzywien i nawiązek w prawie karnym (Dz. U. Nr 95 poz. 475) w części dotyczącej możliwości obniżenia skazanemu za jego zgodą należności za pracę jest niezgodny z art. 1, art. 67 ust. 2 oraz art. 68 Przepisów Konstytucyjnych utrzymanych w mocy na podstawie art. 77 Ustawy Konstytucyjnej z dnia 17 października 1992 r. o wzajemnych stosunkach między władzą ustawodawczą i wykonawczą Rzeczypospolitej Polskiej oraz o samorządzie terytorialnym ${ }^{9}$.

We wniosku Rzecznik wskazywał, że ,przyjęcie w kwestionowanym art. 49 § 3 Kodeksu karnego wykonawczego [z 1969 r. - M.M.], że o wysokości należności za pracę skazanego może decydować on sam, opiera się na założeniu, że skazany ma możliwość wyrażenia swej woli w sposób nieskrępowany. Jest to założenie w dużej mierze błędne, nie uwzględniające specyficznej sytuacji osoby odbywającej karę pozbawienia wolności i jej zależności od administracji zakładu karnego". Ponadto, RPO wskazywał, że kwestionowane brzmienie przepisu „może prowadzić do oferowania przez skazanych swojej pracy za najniższą cenę. Taka zaś rywalizacja może działać demoralizująco i przekreślać możliwość uzyskania efektów resocjalizacyjnych, będących celem wykonania kary pozbawienia wolności”. Wskazywano również, że „W kolejnych nowelizacjach Kodeksu karnego wykonawczego można zaobserwować wyraźną tendencję do zbliżenia w istotnych punktach praw zatrudnionych skazanych do praw pracowniczych (...), nowelizacja art. 49 § 3 Kodeksu karnego wykonawczego [z 1969 r. - M.M.] jest odwróceniem tego słusznego trendu". Rzecznik podnosił, że ,tendencja powyższa była wynikiem realizacji przyjętych lub uznawanych przez Polskę aktów prawa międzynarodowego. Do tych aktów należą przede wszystkim:

- Powszechna Deklaracja Praw Człowieka, stanowiąca, iż każdy bez jakiejkolwiek dyskryminacji ma prawo do równej płacy za równą pracę. (art. 23 ust. 2);

\footnotetext{
${ }^{8}$ Zob. pełny tekst wniosku: http://www.sprawy-generalne.brpo.gov.pl/szczegoly.php?pismo=264050 [dostęp: 3 października 2015 r.].

${ }^{9}$ Dz. U. Nr 84 poz. 426.
} 
- Międzynarodowy Pakt Praw Gospodarczych, Socjalnych i Kulturalnych ratyfikowany przez Polskę w dniu 3 marca 1977 r. zobowiązujący do uznawania praw każdej osoby do słusznych i korzystnych warunków pracy, obejmujących w szczególności "słuszną płacę i równe wynagrodzenie za pracę o równej wartości bez jakiejkolwiek różnicy" (art. 7).

- Reguły Minimum postępowania z więźniami, stanowiące zalecenia I Kongresu ONZ W sprawie zapobiegania przestępczości i postępowania z więźniami, podkreślające, że kara uwięzienia ma charakter dolegliwości przez sam fakt odebrania więźniom prawa stanowienia o sobie przez pozbawienie ich wolności i dolegliwość ta nie powinna być w jakikolwiek sposób zaostrzana".

W wyniku wniosku Rzecznika, Trybunał w orzeczeniu z dnia 7 stycznia 1997 r. (K 7/96) orzekł, iż art. 49 § 3 k.k.w. z 1969 r. w brzmieniu nadanym przez art. 2 pkt 9 lit. a) ustawy z dnia 12 lipca 1995 r. o zmianie Kodeksu karnego, Kodeksu karnego wykonawczego oraz o podwyższeniu dolnych i górnych granic grzywien i nawiązek w prawie karnym rozumiany $\mathrm{w}$ ten sposób, że nie stanowi on podstawy do obniżenia skazanemu należności za pracę poniżej stawki wynagrodzenia minimalnego przysługującego pracownikom - jest zgodny z art. 1, 67 ust. 2 i art. 68 przepisów konstytucyjnych pozostawionych w mocy na podstawie art. 77 Ustawy Konstytucyjnej z dnia 17 października 1992 r. o wzajemnych stosunkach między władzą ustawodawczą i wykonawczą Rzeczypospolitej Polskiej oraz o samorządzie terytorialnym.

Trybunał wskazał w orzeczeniu, iż „odesłanie w art. $49 \S 3$ kodeksu karnego wykonawczego [z 1969 r. - M.M.] do zasad wynagradzania pracowników za pracę tego samego rodzaju, którą wykonuje skazany oznacza, iż także do niego stosuje się stawki wynagrodzenia minimalnego obowiązujące pracowników. Stawki te ustalane są w akcie normatywnym i nie mogą być w drodze oświadczenia woli uchylone. (...) Wprowadzony zaś tą nowelizacją do art. $49 \S 3$ in fine tego kodeksu zwrot ,chyba że skazany wyrazi zgodę na niższe wynagrodzenie” dotyczy jedynie ustalenia niższej należności za pracę skazanego, niżby to wynikało z zasad wynagradzania pracowników za pracę tego rodzaju, a nie uchyla prawa skazanego do należności za pracę w wysokości co najmniej minimalnego wynagrodzenia przysługującego pracownikom. TK dostrzegł również, że „trudności znalezienia pracy dla więźniów, zapewniającej im wynagrodzenie według zasad wynagradzania pracowników, nie uzasadnia jeszcze odstąpienia od zagwarantowania stawki wynagrodzenia minimalnego zatrudnionym odpłatnie więźniom, podobnie jak wysoki stopień bezrobocia nie uzasadnia odstąpienia od stawki wynagrodzenia minimalnego w umowie o pracę". 
Ważne z punktu widzenia tworzenia kolejnych norm $\mathrm{w}$ tej mierze winno być także uzasadnienie, w myśl którego „nie przekonuje też przeciwko stosowaniu stawki wynagrodzenia minimalnego do skazanych argument, iż nie ponoszą oni kosztów swego utrzymania. Nie ma bowiem przeszkód konstytucyjnych w obciążaniu zatrudnionych odpłatnie więźniów za wzorem niektórych państw Europy Zachodniej obowiązkiem partycypacji w kosztach ich utrzymania (tak np. we Francji i w Niemczech, por. Zachodnie ustawy penitencjarne, teksty ustaw z komentarzami, Kalisz 1996, s. 36 i 167). Nie można stawiać znaku równości między potrąceniami z wynagrodzenia na koszty utrzymania więźniów w granicach określonych ustawowo - z pozostawieniem naczelnikom zakładów karnych pełnej swobody określenia $\mathrm{w}$ umowach zawieranych $\mathrm{z}$ pracodawcami wysokości wynagrodzenia przysługującego zatrudnionym więźniom, $\mathrm{z}$ pominięciem stawki wynagrodzenia minimalnego przysługującego pracownikom. Prowadziłoby to do pozbawienia odpłatnie zatrudnionych więźniów elementarnego mechanizmu prawnego ochrony ich pracy przed wyzyskiem".

Trzeba też zauważyć, iż po nowelizacji ustawą z dnia 12 lipca 1995 r. o zmianie Kodeksu karnego, Kodeksu karnego wykonawczego oraz o podwyższeniu dolnych i górnych granic grzywien i nawiązek w prawie karnym, w myśl art. 52 ust. 1 k.k.w. z 1969 r., a później art. $125 \S 1$ ustawy z dnia 6 czerwca 1997 r. Kodeks karny wykonawczy ${ }^{10}$ (dalej: k.k.w.) aż do zmiany k.k.w., która weszła w życie 1 września 2003 r. z należności za pracę (wynagrodzenia) potrącano skazanemu $10 \%$ na cele pomocy postpenitencjarnej; z pozostałej części wynagrodzenia za pracę przypadało skazanemu 50\%, a resztę przekazywano do budżetu państwa.

\section{Zmiana art. $123 \S 1$ k.k.w. z 2003 r. i wyrok Trybunału Konstytucyjnego z dnia} 23 lutego 2010 r. (P 20/09) ${ }^{11}$

Wskutek dalszego pogłębiania się trudności w zakresie odpłatnego zatrudniania skazanych ustawodawca po raz kolejny zmienił zasady wynagradzania skazanych. Z dniem 1 września 2003 r. art. 123 zmieniony przez art. 1 pkt 83 ustawy z dnia 24 lipca 2003 r. o zmianie ustawy - Kodeks karny wykonawczy oraz niektórych innych ustaw ${ }^{12}$ otrzymał nowe brzmienie. W $\S 1$ art. 123 k.k.w. ustanawiał zasadę odpłatności pracy skazanego (praca skazanego jest odpłatna, z zastrzeżeniem art. 123a. Zasady wynagradzania za pracę ustala się w porozumieniu zawieranym przez dyrektora zakładu karnego lub w umowie zawieranej

\footnotetext{
${ }^{10}$ Dz. U. Nr 90, poz. 557, ze zm.

${ }^{11}$ Opis działań RPO jest powiązany ze zmianą normatywną jaka dokonała się po wyroku TK z dnia 23 lutego $2010 \mathrm{r}$. stąd potrzeba ujęcia tego zagadnienia w publikacji.

${ }^{12}$ Dz. U. Nr 142, poz. 1380.
} 
przez skazanego. Przy skierowaniu skazanego do prac administracyjno-porządkowych na terenie zakładu karnego, wynagrodzenie za pracę ustala dyrektor tego zakładu), dookreślając w $\S 2$ art. 123 k.k.w., że „wynagrodzenie przysługujące skazanemu zatrudnionemu w pełnym wymiarze czasu pracy ustala się w sposób zapewniający osiągnięcie co najmniej połowy minimalnego wynagrodzenia określonego na podstawie odrębnych przepisów, przy przepracowaniu pełnego miesięcznego wymiaru czasu pracy lub wykonaniu pełnej miesięcznej normy pracy. W wypadku przepracowania niepełnej miesięcznej normy czasu pracy lub niewykonania pełnej miesięcznej normy pracy wynagrodzenie wypłaca się proporcjonalnie do ilości czasu pracy lub wykonanej normy pracy. W razie zatrudnienia skazanego w niepełnym wymiarze czasu pracy najniższe wynagrodzenie ustala się w kwocie proporcjonalnej do liczby godzin zatrudnienia, biorąc za podstawę połowę minimalnego wynagrodzenia".

Ustawodawca uzasadniał tę zmianę następująco: „Proponowane zmiany art. 123, $123^{1}$ i $125 \mathrm{w}$ powiązaniu z omawianą wcześniej zmianą art. 43 § 1 mają na celu zmniejszenie kosztów pracy skazanych ponoszonych przez pracodawców i tym samym zwiększenie możliwości zatrudnienia skazanych, dla których obecnie faktycznie nie ma pracy ${ }^{13}$. Zmiany te pozwolą w szczególności:

- zagwarantować skazanym zatrudnionym odpłatnie wynagrodzenie w wysokości nie mniejszej niż 50\% najniższego wynagrodzenia pracowniczego, ponieważ skazani nie ponoszą żadnych kosztów związanych z utrzymaniem, wyżywieniem itp.;

- zrezygnować z przekazywania części wynagrodzenia skazanych na dochody budżetowe, ponieważ przy braku ofert pracy ze strony ewentualnych kontrahentów, istnieje potrzeba obniżenia kosztów pracy skazanych ponoszonych przez pracodawców;

- uregulować potrącanie części wynagrodzenia na cele pomocy postpenitencjarnej wyłącznie $\mathrm{W}$ art. $43 \mathrm{z}$ wprowadzeniem jednocześnie zasady potrącania jednakowej części wynagrodzenia lub dochodu wszystkim skazanym, bez względu na rodzaj zatrudnienia;

- zrezygnować z podwyższania wynagrodzeń skazanych, na których ciąży obowiązek alimentacyjny ze względu na to, że środki przeznaczone na podwyższanie wynagrodzeń pochodziły z części przeznaczonej na dochody budżetowe.

Zwiększenie liczby godzin, którą skazany zobowiązany jest przepracować nieodpłatnie z obowiązujących 60 do proponowanych 90 jest uzasadnione ograniczonymi

\footnotetext{
${ }^{13}$ Cel, jaki stał u podstaw zmiany art. 123 k.k.w., został osiągnięty, bowiem po 2003 r. widoczny jest wyraźny wzrost zatrudnienia skazanych, zob. W. Majewski, Z. Migal, Zatrudnienie więźniów (w:) Księga jubileuszowa więziennictwa polskiego 1989-2009, red. T. Szymanowski, J. Cegielska, J. Czołgoszewski, S. Lelental, J. Pomiankiewicz, Warszawa 2009, s. 197.
} 
środkami przeznaczonymi na wynagradzania skazanych zatrudnionych przy pracach porządkowych i pomocniczych oraz koniecznością zróżnicowania płac skazanych, zatrudnionych na różnych stanowiskach.

Dodatkowo, regulacja zawarta w art. 123 ujednolica zasady wynagradzania skazanych za pracę tego samego rodzaju $\mathrm{w}$ stosunku do innych osób zatrudnionych $\mathrm{u}$ danego pracodawcy oraz określa efektywny czas pracy, dając równocześnie możliwość zatrudniającemu powierzenia skazanemu innej pracy w czasie przestoju za zgodą dyrektora zakładu"14.

W uzasadnieniu w części zatytułowanej „Inne zmiany” ustawodawca wyjaśnia dodatkowo, że „integralną częścią, z punktu widzenia przyjętych nowych rozwiązań $\mathrm{w}$ zakresie zasad wynagradzania skazanych, o których mowa $\mathrm{w}$ art. 123, jest zmiana zaproponowana $\mathrm{w}$ art. 2 nowelizacji, dotyczącym zmiany w art. 23 ust. 1 ustawy o zatrudnieniu i przeciwdziałaniu bezrobociu. Proponowana zmiana ma charakter dostosowujący tę ustawę do nowelizacji Kodeksu karnego wykonawczego i ma na celu umożliwienie skazanym po opuszczeniu zakładu karnego, w przypadku nieznalezienia pracy, otrzymywania zasiłku dla bezrobotnych mimo tego, że nie otrzymywali oni podczas zatrudnienia w zakładzie karnym wynagrodzenia w wysokości najniższego miesięcznego wynagrodzenia, o którym mowa w Kodeksie pracy”.

Brzmienie art. $123 \S 2$ k.k.w. zostało poddane ocenie Trybunału Konstytucyjnego wskutek pytania prawnego Sądu Rejonowego w Gliwicach w zakresie zgodności tego przepisu z art. 65 ust. 4 w zw. z art. 31 ust. 3 i art. 2 oraz art. 32 Konstytucji Rzeczypospolitej Polskiej z dnia 2 kwietnia 1997 r. ${ }^{15}$ (dalej: Konstytucja RP).

Pytanie prawne zostało postawione w związku z powództwem osoby odbywającej karę pozbawienia wolności przeciwko Skarbowi Państwa - Zakładowi Karnemu nr 1

\footnotetext{
${ }^{14}$ Zob. uzasadnienie poselskiego projektu ustawy. Sejm RP IV kadencji, Nr druku: 389. W opinii prawnej M. Płatek z dnia 14 maja 2002 pt. Opina prawna do projektu ustawy o zmianie ustawy - kodeks karny wykonawczy oraz niektórych innych ustaw (druk $n r$ 389) - projekt poselski, jej autorka poddała krytyce (w kwestii zatrudnienia skazanych) jedynie projekt art. 121 k.k.w., w zakresie w jakim wyklucza możliwość samozatrudnienia skazanych.

Z kolei w opinii (do prezydenckiego projektu ustawy. Sejm RP IV kadencji, $\mathrm{Nr}$ druku: 183) W. OdrowążaSypniewskiego z dnia 6 marca 2003 r. pt. Opinia $w$ sprawie zgodności z Konstytucja RP projektowanego brzmienia art. $123 \S 2$ Kodeksu karnego wykonawczego, jej autor wyraźnie wskazuje, iż ,art. $123 \S 2$ w proponowanym brzmieniu jest niezgodny z art. $32 \mathrm{w}$ związku z art. 65 ust. 4 Konstytucji RP. Kryterium uzasadniające ustanowienie niższej wysokości minimalnego wynagrodzenia za pracę $\mathrm{w}$ przypadku osób, o których mowa w art. $123 \S 2$ nie ma bowiem charakteru relewantnego z punktu widzenia celu i treści przepisów konkretyzujących konstytucyjne pojęcie "minimalnej wysokości wynagrodzenia za pracę". Kryterium takie przeczy również istocie konstytucyjnego prawa do uzyskiwania za świadczoną pracę wynagrodzenia minimalnego czyli - jak wskazał Trybunał Konstytucyjny - wynagrodzenia wystarczającego na zaspokojenie pewnych uzasadnionych potrzeb życiowych jednostki (minimalnego standardu godnego życia)".

${ }^{15}$ Dz. U. Nr 78, poz. 483 ze zm.
} 
w Strzelcach Opolskich oraz Przedsiębiorstwu Przemysłu Obuwniczego-Przedsiębiorstwu Państwowemu w Strzelcach Opolskich. Powód w okresie odbywania kary na swój wniosek został skierowany do pracy na podstawie decyzji dyrektora zakładu karnego. W okresie od 6 czerwca 2006 r. do 10 lipca 2008 r. świadczył pracę w wymienionym przedsiębiorstwie, uzyskując wynagrodzenie niższe od minimalnego.

W wyroku z dnia 23 lutego 2010 r. (P 20/09) Trybunał orzekł, iż:

1. Art. $123 \S 2$ zdanie pierwsze ustawy z dnia 6 czerwca 1997 r. - Kodeks karny wykonawczy (Dz. U. Nr 90, poz. 557, ze zm.) w zakresie, w jakim zawiera słowo "połowy", jest niezgodny z art. 32 oraz z art. 65 ust. 4 w związku z art. 2 Konstytucji Rzeczypospolitej Polskiej.

2. Przepis wymieniony w części I, w zakresie tam wskazanym, traci moc obowiązującą z upływem 12 (dwunastu) miesięcy od dnia ogłoszenia wyroku w Dzienniku Ustaw Rzeczypospolitej Polskiej ${ }^{16}$.

W uzasadnieniu wyroku Trybunał zwrócił uwagę na kilka kwestii:

- praca osób skazanych musi zatem zostać unormowana w taki sposób, aby zapewnić pełną ochronę ich godności i uczynić zadość wymogom odpowiedniego traktowania tych osób. Jednocześnie z art. 30 Konstytucji wynika fundamentalna zasada interpretacyjna in dubio pro dignitate. Konstytucyjna zasada poszanowania godności człowieka stanowi źródło ważnych dyrektyw interpretacyjnych, które znajdują zastosowanie nie tylko przy interpretacji aktów normatywnych podkonstytucyjnych, lecz także w sytuacjach, w których szczegółowe przepisy konstytucyjne mogą budzić wątpliwości interpretacyjne na gruncie ich wykładni językowej;

- w rozpoznawanej sprawie szczególnie istotne znaczenie mają międzynarodowe standardy dotyczące traktowania więźniów. Należy wymienić tu w szczególności dwa ważne dokumenty: Europejskie Reguły Więzienne przyjęte w 2006 r. przez Komitet Rady Ministrów Rady Europy (zob. rekomendacja Rec (2006)2 Komitetu Ministrów do państw członkowskich w sprawie Europejskich Reguł Więziennych, dalej: Europejskie reguły więzienne) oraz Wzorcowe Reguły Minimalne Postępowania z Więźniami przyjęte w 1955 r. przez I Kongres Narodów Zjednoczonych w sprawie zapobiegania przestępczości i postępowania ze sprawcami przestępstw i zaaprobowane przez Radę Gospodarczą i Społeczną (zob. rezolucja 663C (XXIV) z dnia 31 lipca 1957 r. oraz 2076 (LXII) z 13 maja 1977 r. (...). Dokumenty te kładą nacisk na prawo więźniów do sprawiedliwego wynagrodzenia za wykonywaną pracę. Z konstytucyjnego nakazu humanitarnego traktowania więźniów można zatem wyprowadzać ich prawo do sprawiedliwego wynagrodzenia za pracę wykonywaną w okresie pozbawienia

\footnotetext{
${ }^{16}$ Sentencję wyroku opublikowano w Dz. U. z 2010 r. Nr 34, poz. 191 (dzień publikacji: 8 marca 2010 r.)
} 
wolności. Zmuszanie osób skazanych do podejmowania pracy bez zapewnienia im sprawiedliwego wynagrodzenia stanowiłoby przykład naruszenia rozważanej normy konstytucyjnej. Wynagrodzenie za pracę otrzymywane przez skazanego jest sprawiedliwe, jeżeli jest ustalane na podobnych zasadach jak za identyczną pracę wykonywaną przez osoby nieodbywające kary pozbawienia wolności;

- zatrudnienie skazanych sprzyja ograniczeniu powrotowi do przestępstwa. Z tego względu praca osób skazanych nie powinna stanowić czynnika zwiększającego dolegliwość wymierzanej kary, ale musi zostać unormowana w taki sposób, aby ułatwić realizację zasadniczego celu, którym jest resocjalizacja tych osób;

- Konstytucja nie wymaga, aby minimalne wynagrodzenie za pracę zostało ustalone na jednakowym poziomie dla wszystkich pracowników. Konstytucyjna zasada równości nie wyklucza zróżnicowania minimalnego wynagrodzenia za pracę, na przykład na podstawie kryteriów branżowych czy terytorialnych, czy też w zależności od długości okresu zatrudnienia, jeżeli tylko ustanowione różnicowania będą miały charakter usprawiedliwiony i spełnią przedstawione wyżej warunki dopuszczalności różnicowań. Dotyczy to również minimalnego wynagrodzenia za pracę osób skazanych. W świetle powyższych rozważań należy stwierdzić, że ustawodawca ustanawia szczególne regulacje w zakresie minimalnego wynagrodzenia za pracę wykonywaną przez osoby pozbawione wolności. Są one mniej korzystne niż regulacje dotyczące minimalnego wynagrodzenia innych osób świadczących pracę zarobkową;

- z punktu widzenia ustalenia poziomu minimalnego wynagrodzenia za pracę wspólną cechą istotną jest sam fakt świadczenia pracy za wynagrodzeniem, bez względu na to, czy jest to praca w ramach odbywania kary pozbawienia wolności;

- konstytucyjny termin "praca" obejmuje wszelką pracę zarobkową na rzecz innego podmiotu, bez względu na formalne zakwalifikowanie stosunku łączącego te podmioty. Obejmuje on także pracę zarobkową wykonywaną przez osoby pozbawione wolności, bez względu na charakter stosunku prawnego $\mathrm{w}$ ramach którego praca ta jest wykonywana, $\mathrm{w}$ tym pracę wykonywaną przez osoby niebędące pracownikami w rozumieniu kodeksu pracy. Z tych względów zakres stosowania gwarancji minimalnego wynagrodzenia, przewidziany w art. 65 ust. 4 Konstytucji, jest szerszy od zakresu stosowania przepisów kodeksu pracy i obejmuje stosunki prawne spełniające przedstawione tutaj kryteria, nawet jeżeli stosunki te nie podlegają regulacjom zawartym w tym kodeksie;

- Konstytucja nie wyklucza wprowadzenia szczególnych rozwiązań dotyczących dysponowania wynagrodzeniem przez osoby skazane ani też obowiązkowych potrąceń na 
określone cele społeczne. Regulacje te muszą jednak służyć realizacji określonych wartości konstytucyjnych i nie mogą prowadzić do naruszenia zasady równości.

\section{Działania „miękkie” RPO po wydaniu wyroku TK z dnia 23 lutego 2010 r. (P 20/09)}

a) Organizacja debaty na temat „Zatrudnienia osób skazanych w trakcie odbywania kary pozbawienia wolności i po jej zakończeniu”

Przepis art. $123 \S 2$ k.k.w., w zakresie, w jakim zawiera słowo "połowy", utracił moc obowiązującą z upływem 12 miesięcy od dnia ogłoszenia wyroku w Dzienniku Ustaw Rzeczypospolitej Polskiej, tj. z dniem 8 marca 2011 r. W tym dniu, kiedy przestał obowiązywać art. $123 \S 2$ k.k.w. w brzmieniu zakwestionowanym przez Trybunał, weszła w życie ustawa z dnia 3 lutego 2011 r. o zmianie ustawy - Kodeks karny wykonawczy oraz niektórych innych ustaw ${ }^{17}$, będąca wykonaniem wyroku TK.

Widząc drastyczne obniżenie liczby osób zatrudnionych odpłatnie Rzecznik Praw Obywatelskich w dniu 13 września 2012 r. zorganizowała debatę na temat „Zatrudnienia osób skazanych w trakcie odbywania kary pozbawienia wolności i po jej zakończeniu"18.

Poniżej ważniejsze wnioski płynące z debaty ${ }^{19}$ :

1. Powierzenie pewnych rodzajów wytwórczości tylko zakładom karnym i stworzenie obiegu zamkniętego wewnątrz więziennictwa dla towarów i usług oferowanych przez przywięzienne zakłady pracy;

2. Wprowadzenie mediacji do postępowania wykonawczego, dzięki której może dojść do porozumienia między sprawcą a pokrzywdzonym i ustalenia zadośćuczynienia, a pozytywne wyniki mediacji będą prowadzić do wcześniejszego opuszczenia zakładu karnego przez osadzonego;

3. Wyłączenie (do określonej kwoty) przywięziennych przedsiębiorstw i gospodarstw pomocniczych od stosowania ustawy z dnia 29 stycznia 2004 r. - Prawo zamówień publicznych ${ }^{20}$;

\footnotetext{
${ }^{17}$ Dz. U. Nr 39, poz. 202.

${ }^{18}$ Zapis dźwiękowy debaty: https://www.rpo.gov.pl/sites/default/files/Debata_Zatrudnienie_osob_skazanych_z_ dnia_13-09-2012_r_cz.\%20I_13-09-2012\%20czI.mp3

https://www.rpo.gov.pl/sites/default/files/Debata_Zatrudnienie_osob_skazanych_z_dnia_13-09-

2012_r_cz_II.mp3 [dostęp: 3 października 2015 r.].

19 Wszystkie wnioski są dostępne pod adresem: https:/www.rpo.gov.pl/pl/content/krajowy-mechanizmprewencji-zorganizowa $\%$ C5\%82-w-biurze-rzecznika-praw-obywatelskich-debat $\%$ C4\%99

[dostęp: 3 października 2015 r.].

${ }^{20}$ Postulat został zrealizowany, zob. ustawa z dnia 26 lipca 2013 r. o zmianie ustawy - Prawo zamówień publicznych (Dz. U. poz. 1047).
} 
4. Obniżenie kosztów związanych z zatrudnieniem skazanych poprzez rezygnację wzorem niektórych państw europejskich - z należności podatkowych wobec Skarbu Państwa (z niepodatkowych należności budżetowych i niektórych innych opłat, np. za użytkowanie wieczyste, zwolnione są przywięzienne zakłady pracy - art. 6 ust. 1 ustawy z dnia 28 sierpnia 1997 r. o zatrudnianiu osób pozbawionych wolności ${ }^{21}$ ) oraz wprowadzenie przy jednostkach penitencjarnych tzw. małych stref ekonomicznych zwolnionych z podatków dla zatrudniających skazanych;

5. Umożliwienie uzyskiwania środków z Funduszu Aktywizacji Zawodowej Skazanych przez organizacje pozarządowe;

6. Rozszerzenie uprawnień Służby Więziennej tak, aby funkcjonariusze mogli pełnić dozór przy więźniach odbywających karę pozbawienia wolności w zakładach karnych typu zamkniętego pracujących poza jednostką i otrzymywać za to wynagrodzenie od pracodawcy zatrudniającego osoby pozbawione wolności;

7. Skrócenie okresu, po upływie którego następuje zatarcie skazania i wykreślenie informacji o skazaniu z Krajowego Rejestru Karnego;

8. Wprowadzenie możliwości zawieszenia albo ograniczenia egzekucji komorniczej w określonym okresie po opuszczeniu przez skazanego zakładu karnego, umożliwiające byłym więźniom usamodzielnienie się oraz ograniczające zatrudnienie w szarej strefie (uciekanie do szarej strefy ma miejsce, gdy osoba, która opuściła jednostkę penitencjarną podejmie pracę w oparciu o umowy cywilnoprawne, gdzie nie ma żadnych ograniczeń co do możliwości egzekucji z tych środków przez komornika);

9. Zmiana instytucji przygotowania skazanego do zwolnienia z zakładu karnego na podstawie art. 164 k.k.w. (obecnie przepisy nie precyzują, jaki kurator - kurator właściwy ze względu na położenie zakładu karnego, w którym przebywa skazany, czy kurator właściwy ze względu na przyszłe miejsce zamieszkania skazanego - powinien realizować czynności w trybie art. 164 k.k.w. Przy braku faktycznej możliwości odbywania przez skazanych kary w zakładach karnych położonych najbliżej przyszłego miejsca zamieszkania, przygotowanie do życia na wolności przez kuratora, np. poprzez pomoc w znalezieniu zatrudnienia po zwolnieniu, jest w praktyce niemożliwe);

10. Ograniczanie liczby skazanych odbywających karę pozbawienia wolności i zwiększenie populacji skazanych odbywających karę w systemie dozoru elektronicznego (zmiana filozofii karania);

\footnotetext{
${ }^{21}$ Tekst jedn. Dz. U. z 2014 r. poz. 1116.
} 
11. Likwidacja ograniczeń stawianych osadzonym przez samą Służbę Więzienną w dostępie do zatrudnienia, tj. stosowanie $\mathrm{w}$ praktyce zasady indywidualizacji w postępowaniu wobec osób pozbawionych wolności i kierowanie do zatrudnienia skazanych z drugą sprawą śledczą, tymczasowo aresztowanych oraz skazanych z różnym stopniem niepełnosprawności. Tylko w indywidualnych przypadkach o odmowie zatrudnienia winno decydować dobro postępowania karnego, wiek lub stan zdrowia;

12. Zwiększenie skali zatrudnienia nieodpłatnego wobec braku możliwości zatrudnienia odpłatnego;

13. Konsolidacja bazy produkcyjnej, np. w skali okręgowych inspektoratów Służby Więziennej, ze sprawną pod względem organizacyjnym strukturą odpowiedzialną za produkcję, tj. nastawioną na menadżerskie, a nie administracyjne, metody zarządzania;

14. Wzorem sprawdzonej praktyki państw europejskich (np. Wielkiej Brytanii), uruchomienie $\mathrm{w}$ terenie specjalnych rad, skupiających przedstawicieli administracji penitencjarnej, władz lokalnych, prywatnych przedsiębiorców oraz związków zawodowych. Rozwijałyby one zatrudnienie u kontrahentów pozawięziennych. Do tego celu można wykorzystać przewidzianą w art. 40 k.k.w. organizację rad terenowych do spraw społecznej readaptacji i pomocy skazanym;

15. Rozwój spółdzielni socjalnych w zakładach karnych;

16. Propagowanie i wspieranie form samozatrudnienia skazanych;

17. Kierowanie osadzonych do bardziej skomplikowanych prac i podnoszenie kwalifikacji skazanych oraz umożliwienie przekwalifikowania zawodowego skazanych z uwzględnieniem zawodów „,przyszłościowych” np. animatora kultury;

18. Tworzenie w zakładach karnych list skazanych, którzy mogą zastąpić osadzonych już pracujących w dniach, w których nie mogą stawić się do pracy m.in. z przyczyn leżących po stronie jednostki penitencjarnej czy w związku z prowadzonym postępowaniem sądowym;

19. Inwentaryzacja hal, budynków, terenów, jakimi dysponuje więziennictwo, celem ich wykorzystania, udostępnienia, wynajęcia przyszłym pracodawcom;

20. Korelacja oddziaływań, którym poddawani są skazani w trakcie odbywania kary z programami postpenitencjarnymi, zintegrowanie systemu pomocy postpenitencjarnej świadczonej przez różne podmioty oraz wsparcie organizacji pozarządowych realizujących zadania związane z ułatwieniem skazanym readaptacji społecznej;

21. Realizacja szkoleń zawodowych odpowiadających potrzebom rynku pracy, prowadzenie doradztwa zawodowego i programów rozwijających umiejętności niezbędne z punktu widzenia uzyskania i utrzymania zatrudnienia, a także profesjonalnie 
przygotowanych warsztatów, dzięki którym skazani zdobędą pewne umiejętności interpersonalne oraz zawodowe ułatwiające im znalezienie zatrudnienia;

22. Kierowanie odpowiednio przeszkolonych skazanych do pracodawców zewnętrznych celem odbycia stażu lub praktyki zawodowej.

b) Spotkanie RPO z Prezesem Trybunału Konstytucyjnego

Rzecznik Praw Obywatelskich po spotkaniu z Prezesem Trybunału Konstytucyjnego wskazała $^{22}$, iż według Niego intencja Trybunału co do wyroku P 20/09 nie została właściwie odczytana przez ustawodawcę (Trybunał reprezentowany przez Prezesa TK dopuszcza możliwość różnicowania wynagrodzenia). W tej sytuacji RPO poleciła, aby spróbować spojrzeć na ww. wyrok krytycznie i zaproponować inne rozwiązania w kwestii zatrudnienia osób pozbawionych wolności.

Wydaje się, iż możliwa jest następująca interpretacja wyroku Trybunału:

Kwestie minimalnego wynagrodzenia osób odbywających karę pozbawienia wolności zatrudnionych w ramach stosunku pracy (art. 2 ustawy z dnia 26 czerwca 1974 r. Kodeksu pracy $^{23}$ ) można byłoby uregulować w następujący sposób:

1) w k.k.w. wprowadzić przepis odsyłający do ustawy z dnia 10 października 2002 r. o minimalnym wynagrodzeniu za pracę ${ }^{24}$,

2) natomiast $\mathrm{w}$ ustawie o minimalnym wynagrodzeniu za pracę, przepis wzorowany na art. 6 ust. 2 tej ustawy, a dotyczącym absolwentów podejmujących zatrudnienie, dla których przewiduje się $80 \%$ minimalnego wynagrodzenia za pracę. Do ustawodawcy należałoby określenie, jaki poziom wynagrodzenia minimalnego dla osób pozbawionych wolności, będzie im wystarczał na zaspokojenie pewnych uzasadnionych potrzeb życiowych.

W przypadku osób świadczących pracę na podstawie skierowania w zasadzie można byłoby rozważyć dwie możliwości:

1) w k.k.w. - określenie minimalnych stawek za pracę, ale bez odwołania do minimalnego wynagrodzenia za pracę;

2) albo w ustawie o minimalnym wynagrodzeniu za pracę - odrębne uregulowanie, chociaż w takiej sytuacji pojawia się pewien problem, ponieważ ustawa o minimalnym wynagrodzeniu znajduje zastosowanie do pracowników; gdybyśmy określili w niej wynagrodzenie osób świadczących pracę na podstawie skierowania, powstaje pytanie, czy nie

\footnotetext{
22 Wypowiedz, podczas wystąpienia w dniu 11 czerwca 2014 r. prezentującego Raport roczny RPO z działalności KMP za 2013 r.

${ }^{23}$ Tekst jedn. Dz. U. z 2014 r. poz. 1502 ze zm.

${ }^{24}$ Dz. U. Nr 200, poz. 1679 ze zm.
} 
powinna ona również określać minimalnego wynagrodzenia za pracę osób zatrudnionych na podstawie umów cywilnoprawnych?

Idąc tokiem rozumowania TK, najlepiej byłoby przyznać osobom odbywającym karę pozbawienia wolności minimalne wynagrodzenie za pracę, a następnie część tego wynagrodzenia przeznaczyć na cele społeczne bądź na pokrycie kosztów utrzymania więźniów $^{25}$, wówczas nie można by takiemu rozwiązaniu postawić zarzutu naruszenia art. 32 Konstytucji RP. W takiej jednak sytuacji nie wpłynie to na „atrakcyjność w zatrudnianiu tych osób”.

Możliwość różnicowania wynagrodzenia skazanych wydaje się być zatem możliwa jedynie poprzez zmiany w ustawie o minimalnym wynagrodzeniu, zaproponowane wyżej, i to przy założeniu zachowania podziału form zatrudnienia, o którym mowa w art. $121 \S 2$ k.k.w. (skazanego zatrudnia się na podstawie skierowania do pracy albo umożliwia się skazanemu wykonywanie pracy zarobkowej w ramach umowy o pracę, umowy zlecenia, umowy o dzieło, umowy o pracę nakładczą lub na innej podstawie prawnej).

Trzeba zauważyć, iż krytycznie do wyroku Trybunału odniesiono się również w doktrynie. Według T. Kalisza i A. Kwiecińskiego:

- przywołane przez Trybunał dokumenty międzynarodowe [Europejskie Reguły Więzienne i Reguły minimalne - M.M.], w żadnym miejscu nie mówią, że praca zarobkowa skazanych musi być zrównana $\mathrm{z}$ pracą osób wolnych, co więcej, dokumenty te unikają takiego zrównania;

- od momentu wejścia w życie orzeczenia widoczne jest wyraźne ograniczenie zatrudnienia odpłatnego (z 21.298 osadzonych w 2007 r. do 9.167 osadzonych w 2013 r. przy zbliżonej liczbie wszystkich osadzonych w jednostkach penitencjarnych) na rzecz wzrostu zatrudnienia nieodpłatnego (z 6.525 osadzonych w 2007 r. do 15.125 osadzonych w 2013 r.), co jest niezamierzonym skutkiem orzeczenia;

- regulacje innych demokratycznych państw zachodniej Europy nie zrównują wynagrodzenia osób pozbawionych wolności i osób nieodbywających tej kary ${ }^{26}$.

\section{Inne działania Rzecznika Praw Obywatelskich}

a) Niewłaściwa interpretacja przepisu Kodeksu karnego wykonawczego obligującego do pisemnego powiadomienia skazanego o cofnięciu zgody na zatrudnienie

\footnotetext{
${ }^{25}$ Należy wskazać, iż np. w Austrii wynagrodzenie za pracę więźniów, przeznaczane jest w większości na pokrycie kosztów ich utrzymania, zob. K. Wójcik-Adamska, Zatrudniony więzień bez emerytury, http://www4.rp.pl/artykul/706328-Wiezniowie-zatrudnieni-ale-bez-emerytury.html [dostęp: 3 października 2015 r.].

${ }^{26}$ T. Kalisz, A. Kwieciński, Zmiany w zakresie..., s. 24-30.
} 
Do Rzecznika zwrócił się osadzony, który żalił się, iż dyrektor zakładu karnego, wydając decyzję o wycofaniu z zatrudnienia, nie powiadomił go o tym fakcie pisemnie. Dyrektor Okręgowy Służby Więziennej nie stwierdził nieprawidłowości w działaniu administracji zakładu karnego, przyjmując, że skoro skarżący był zatrudniony na podstawie skierowania do pracy, a nie na podstawie umowy o pracę, umowy zlecenie, umowy o dzieło lub na innej podstawie prawnej, brak pisemnego powiadomienia skazanego o wycofaniu zgody na zatrudnienie nie stoi w sprzeczności z przepisem art. $121 \S 4$ k.k.w. Również Kierownik Zespołu do spraw Skarg Osób Pozbawionych Wolności w Biurze Prawnym Centralnego Zarządu Służby Więziennej uznał, że przepis art. $121 \S 4$ k.k.w. nie dotyczy zatrudnienia $\mathrm{w}$ ramach skierowania do pracy. Przedstawiona interpretacja powyższego przepisu nie została zaakceptowana przez Rzecznika. Według RPO, ustawodawca w art. 121 $\S 2$ k.k.w. zdefiniował formy zatrudnienia. Należy zatem rozumieć, że treść $\S 3$, jak i $\S 4$ art. 121 k.k.w. odnosi się do wszystkich form zatrudnienia skazanego. Nie ma więc podstawy, by sądzić, że przepis art. $121 \S 4$ k.k.w., który obliguje do powiadomienia pisemnego skazanego o cofnięciu zgody na zatrudnienie, wyłącza jedną $\mathrm{z}$ tych form. W myśl powyższego, dyrektor jednostki penitencjarnej ma obowiązek powiadomienia na piśmie skazanego o wycofaniu $\mathrm{z}$ zatrudnienia, $\mathrm{w}$ tym z zatrudnienia na podstawie skierowania do pracy. W związku z powyższym Rzecznik zwrócił się ${ }^{27}$ do Dyrektora Generalnego Służby Więziennej z prośbą o podjęcie stosownych czynności zmierzających do wyeliminowania stosowanej w jednostkach penitencjarnych błędnej praktyki w omawianym zakresie.

W odpowiedzi poinformowano ${ }^{28}$ Rzecznika, że po ponownym przeanalizowaniu sprawy przez radców prawnych zmieniono stanowisko Centralnego Zarządu Służby Więziennej przyznając, że wykładnia gramatyczna (literalna) obowiązujących przepisów dotyczących zatrudnienia skazanych (art. 121 k.k.w.) prowadzi do wniosków zaprezentowanych w wystąpieniu Rzecznika. W związku z powyższym Dyrektor Generalny Służby Więziennej polecił zmienić dotychczasową praktykę powiadamiania skazanych o wycofaniu z zatrudnienia na podstawie skierowania do pracy i informowania ich o tym fakcie w formie pisemnej.

b) Wystąpienie generalne Rzecznika z dnia 19 sierpnia 2013 r.

Rzecznik Praw Obywatelskich po analizie obowiązującego stanu prawnego, a także mając na uwadze wnioski organizacji pozarządowych, zwrócił się z wystąpieniem

\footnotetext{
27 Pismo RPO z dnia 13 kwietnia 2010 r. (RPO-598248-VII/08). Pismo RPO wraz z odpowiedzią, zob. http://www.sprawy-generalne.brpo.gov.pl/szczegoly.php?pismo=1476712 [dostęp: 3 października 2015 r.].

${ }^{28}$ Odpowiedz Dyrektora Generalnego Służby Więziennej z dnia 18 maja $2010 \mathrm{r}$.
} 
generalnym z dnia 19 sierpnia 2013 r. do Ministra Sprawiedliwości ${ }^{29}$ W sprawie nieuzasadnionego różnicowania sytuacji podmiotów zatrudniających skazanych.

W myśl art. 8 ust. 2 ustawy o zatrudnianiu osób pozbawionych wolności z tytułu zwiększonych kosztów zatrudnienia osób pozbawionych wolności przedsiębiorcy zatrudniający te osoby otrzymują ze środków Funduszu Aktywizacji ryczałt w wysokości 20\% wartości wynagrodzeń przysługujących zatrudnionym osobom pozbawionym wolności; wypłata ryczałtu następuje na wniosek tych przedsiębiorców.

Przywołany przepis umożliwia otrzymanie ryczałtu z tytułu zwiększonych kosztów zatrudnienia osób pozbawionych wolności, jednakże tylko podmiotom, które mają status przedsiębiorcy. Stosownie do definicji zawartej w art. 4 ust. 1 ustawy z dnia 2 lipca 2004 r. o swobodzie działalności gospodarczej ${ }^{30}$ przedsiębiorcą w rozumieniu ustawy jest osoba fizyczna, osoba prawna i jednostka organizacyjna niebędąca osobą prawną, której odrębna ustawa przyznaje zdolność prawną - wykonująca we własnym imieniu działalność gospodarczą. Ponadto, za przedsiębiorców uznaje się także wspólników spółki cywilnej w zakresie wykonywanej przez nich działalności gospodarczej (art. 4 ust. 2 ustawy).

Z kolei art. $121 \S 2$ k.k.w. przewiduje, iż skazanego zatrudnia się na podstawie skierowania do pracy albo umożliwia się skazanemu wykonywanie pracy zarobkowej w ramach umowy o pracę, umowy zlecenia, umowy o dzieło, umowy o pracę nakładczą lub na innej podstawie prawnej. Co istotne, zatrudnienie skazanego następuje za zgodą i na warunkach określonych przez dyrektora zakładu karnego, zapewniających prawidłowy przebieg odbywania kary pozbawienia wolności (art. $121 \S 3$ k.k.w.), a w stosunku do skazanych pracujących, w zakresie nieuregulowanym w niniejszym kodeksie [k.k.w. M.M.], stosuje się przepisy prawa pracy” (art. $121 \S 8$ k.k.w.).

Oznacza to, że „w zakresie zatrudniania skazanych mają zastosowanie nie tylko przepisy prawa karnego wykonawczego, ale też - w odniesieniu do umowy o pracę i pracę nakładczą - przepisy prawa pracy, a w zakresie umów zlecenia i o dzieło - przepisy prawa cywilnego". Ponadto, ,jeżeli skazany i pracodawca zaakceptują warunki zatrudnienia, dyrektor zakładu karnego wyraża na to zgodę. Zgoda dotyczy zatrudnienia na warunkach określonych w decyzji o zgodzie na pracę u konkretnego pracodawcy i obowiązuje w okresie przebywania skazanego w zakładzie karnym"31.

\footnotetext{
${ }^{29}$ RPO-695870-VII-720/12/MMa, Zob. https://www.rpo.gov.pl/sites/default/files/Wyst\%C4\%85pienie\%20RPO695870-VII-12\%20do\%20Ministra\%20Sprawiedliwo\%C5\%9Bci\%20z\%20dnia\%2019.08.2013\%20r.pdf [dostęp: 3 października 2015 r.].

${ }^{30}$ Tekst jedn. Dz. U. z 2015 r. poz. 584, ze zm.

${ }^{31}$ K. Postulski, Komentarz do art. 121 kodeksu karnego wykonawczego, LEX/el 2014.
} 
Pracodawcą w myśl art. 3 kodeksu pracy jest jednostka organizacyjna, choćby nie posiadała osobowości prawnej, a także osoba fizyczna, jeżeli zatrudniają one pracowników.

Obowiązujące przepisy umożliwiają zatrudnianie osób pozbawionych wolności także $\mathrm{u}$ innych podmiotów niż tylko przedsiębiorcy, dlatego też ograniczenie możliwości wypłaty ryczałtu z tytułu zwiększonych kosztów zatrudnienia osób pozbawionych wolności do tych ostatnich nie znajduje uzasadnienia.

Jako podmioty zainteresowane zatrudnieniem wymienić należy chociażby organizacje pożytku publicznego (stowarzyszenia, fundacje), które co do zasady nie prowadzą działalności gospodarczej. Fakt, iż obowiązujące przepisy na to pozwalają (art. 34 ustawy z dnia 7 kwietnia 1989 r. Prawo o stowarzyszeniach, art. 5 ust. 5 ustawy z dnia 6 kwietnia 1984 r. o fundacjach) nie oznacza, że te podmioty chętnie z tego uprawnienia korzystają, albowiem nie jest to ich zasadniczy cel działalności.

Jak zauważono w doktrynie, „w przypadku osób prawnych, które prowadzą działalność non for profit, działalność gospodarcza (zarobkowa) jest działalnością akcesoryjną (uboczną). Przedmiotem działalności tych osób jest bowiem prowadzenie aktywności niezarobkowej (charytatywnej, społecznej). Możliwość wykonywania przez nie działalności gospodarczej, i tym samym uzyskania statusu przedsiębiorcy, dotyczy wyłącznie aktywności ubocznej, np. działalność gospodarcza podejmowana przez stowarzyszenia, fundacje $^{32}$. Dlatego też w piśmiennictwie pojawił się pogląd o konieczności rozróżnienia przez ustawę o swobodzie działalności gospodarczej podmiotów prowadzących działalność gospodarczą jako zajęcie główne i akcesoryjne (zob. G. Materna, Pojęcie przedsiębiorcy..., s. 66). Wskazano również, że podmioty prowadzące działalność gospodarczą jako działalność uboczną (akcesoryjną) nie powinny być zaliczane do kategorii przedsiębiorców (tak C. Kosikowski, Przedsiębiorca..., s. 34 i n.) ${ }^{33 \prime \prime}$.

W ocenie Rzecznika obecny kształt regulacji (art. 8 ust. 2 ustawy o zatrudnianiu osób pozbawionych wolności) budzi wątpliwość co zgodności z art. 32 Konstytucji RP, który w ust. 1 stanowi, że wszyscy są wobec prawa równi. Wszyscy mają prawo do równego traktowania przez władze publiczne, w ustępie 2 natomiast, że nikt nie może być dyskryminowany w życiu politycznym, społecznym lub gospodarczym z jakiejkolwiek przyczyny.

L. Garlicki wskazuje, iż „równość w prawie odnosi się do procesu stanowienia prawa i nakłada na prawodawcę obowiązek nadawania prawu takich treści, które czynią zadość

\footnotetext{
${ }^{32}$ M. Zdyb, Prawo działalności gospodarczej. Komentarz, Warszawa 2000, s. 52

${ }^{33}$ M. Sieradzka, Komentarz do art. 4 ustawy o swobodzie działalności gospodarczej, LEX/el. 2012.
} 
nakazowi jednakowego traktowania podmiotów (sytuacji) podobnych". Dalej wskazany autor podaje, że „postulat równości nie może być utożsamiany z nakazem identyczności. Celem i istotą regulacji prawnych jest wprowadzanie zróżnicowań. Dopóki te zróżnicowania prawne odpowiadają obiektywnie istniejącym różnicom między adresatami norm prawnych, problem naruszenia zasady równości nie powstaje. (...) Pytanie o naruszenie zasady równości pojawia się dopiero w sytuacji, gdy wprowadzone zróżnicowania dotyczą podmiotów (sytuacji) podobnych. Wówczas konieczne staje się wykazanie, że wprowadzenie danego zróżnicowania jest uzasadnione, w przeciwnym zaś razie trzeba uznać, że prawodawca dopuścił się konstytucyjnie zakazanej dyskryminacji”34.

Trzeba zauważyć, iż wśród pomiotów, które mogą zatrudniać osoby pozbawione wolności, o wypłatę ryczałtu ubiegać się mogą jedynie przedsiębiorcy, podczas gdy wszystkie podmioty, a więc tak przedsiębiorcy, jak i inne podmioty zatrudniające osoby pozbawione wolności, ponoszą dodatkowe (podwyższone) koszty zatrudniania takich osób.

Wydaje się, iż ustawodawca, przygotowując zmianę przepisów po wydaniu wyroku Trybunału z dnia 23 lutego 2010 r. (P 20/09), nie rozważał kwestii umożliwienia korzystania $\mathrm{z}$ ryczałtu, o którym mowa w art. 8 ust. 2 ustawy o zatrudnianiu osób pozbawionych wolności, przez podmioty inne niż przedsiębiorcy. Jak można sądzić, ustawodawca częściowo kierował się wskazaniem zawartym w samym wyroku Trybunału, który podał, że „w ocenie Trybunału Konstytucyjnego, istnieją alternatywne środki obniżania kosztów pracy osób skazanych, nieprowadzące do obniżania wynagrodzenia za pracę poniżej poziomu wynagrodzenia minimalnego. Należą do nich w szczególności odpowiednie regulacje prawa podatkowego, a także rozmaite bodźce finansowe dla przedsiębiorców zatrudniających osoby skazane".

Tylko częściowe kierowanie się wskazówkami Trybunału zawartymi w wyroku wynika z faktu, że w art. 8 ust. 3 ustawy o zatrudnianiu osób pozbawionych wolności, ustawodawca przyjął, że ze środków Funduszu Aktywizacji mogą być przyznawane pożyczki bądź dotacje podmiotom zatrudniającym osoby pozbawione wolności. Zatem, w przytoczonym przepisie oraz w przepisach wykonawczych (§ 7 ust. 2 i 3 rozporządzenia Ministra Sprawiedliwości z dnia 23 stycznia 2012 r. w sprawie Funduszu Aktywizacji Zawodowej Skazanych oraz Rozwoju Przywięziennych Zakładów Pracy ${ }^{35}$ ) ustawodawca nie

\footnotetext{
${ }^{34}$ L. Garlicki, Komentarz do art. 32 Konstytucji. Komentarz. T. III, Wydawnictwo Sejmowe, Warszawa 2003, s. 10.

${ }^{35}$ Tekst jedn. Dz. U. z 2014 r. poz. 53.
} 
posługuje się konsekwentnie pojęciem przedsiębiorcy, przyjmując, iż z innych form wsparcia zatrudnienia może korzystać także podmiot zatrudniający osoby pozbawione wolności.

Wynika to również z uzasadnienia do ustawy z dnia 3 lutego 2011 r. o zmianie ustawy - Kodeks karny wykonawczy oraz niektórych innych ustaw ${ }^{36}$. W jednym miejscu uzasadnienia o Funduszu Aktywizacji Zawodowej Skazanych oraz Rozwoju Przywięziennych Zakładów Pracy wskazuje się, że „ma to być instrument dostarczający zachęt dla przedsiębiorców, którzy zatrudniają skazanych lub zdecydują się w przyszłości na zaoferowanie im pracy”. W innym natomiast, że „środki nowego funduszu będą mogły być przeznaczane na pomoc adresowaną do - ogólnie rzecz biorąc - "podmiotów zatrudniających osoby pozbawione wolności", a przybierającą tak jak dotąd postać pożyczek tudzież dotacji (zakłada się, że środki Funduszu Aktywizacji Zawodowej Skazanych oraz Rozwoju Przywięziennych Zakładów Pracy służyć będą głównie pokrywaniu następujących kosztów: badań wstępnych, okresowych oraz specjalistycznych z zakresu medycyny pracy, szkoleń z zakresu bhp i ochrony przeciwpożarowej, szkoleń specjalistycznych niezbędnych do podjęcia pracy na konkretnych stanowiskach pracy, transportu więźniów do i z miejsca pracy, zakupu oraz konserwacji odzieży ochronnej i wreszcie - zakupu napojów i posiłków regeneracyjnych)".

Rzecznik Praw Obywatelskich zauważył, że podmioty zatrudniające osoby pozbawione wolności inne niż przedsiębiorcy są dyskryminowane w zakresie uzyskiwania wspomnianego ryczałtu.

Kierując się wskazaniami Trybunału Konstytucyjnego, trzeba zauważyć, że ocena konstytucyjności każdego prawnego zróżnicowania sytuacji podmiotów podobnych zawsze musi wynikać z ustalenia, czy zróżnicowaniu temu można przypisać uzasadniony charakter. W orzeczeniu z dnia 3 września 1996 r. (K 10/96, ten pogląd został wyrażony również w innych orzeczeniach, np. z dnia 18 grudnia 2000 r., K 10/00, z dnia 6 marca 2001 r., K 30/00, z dnia 24 października 2001 r. SK 22/01) Trybunał wskazał, że „wszelkie odstępstwo od nakazu równego traktowania podmiotów podobnych musi zawsze znajdować podstawę w odpowiednio przekonywujących argumentach. Argumenty te muszą mieć:

- po pierwsze, charakter relewantny, a więc pozostawać w bezpośrednim związku z celem i zasadniczą treścią przepisów, w których zawarta jest kontrolowana norma oraz służyć realizacji tego celu i treści. Innymi słowy, wprowadzane zróżnicowania muszą mieć charakter

\footnotetext{
${ }^{36}$ Dz. U. Nr 39, poz. 202.
} 
racjonalnie uzasadniony. Nie wolno ich dokonywać według dowolnie ustalonego kryterium (orzeczenie z 12 grudnia 1994 r., K 3/94, OTK w 1994 r., cz. II, s. 141);

- po drugie, argumenty te muszą mieć charakter proporcjonalny, a więc waga interesu, któremu ma służyć różnicowanie sytuacji adresatów normy, musi pozostawać w odpowiedniej proporcji do wagi interesów, które zostaną naruszone w wyniku nierównego potraktowania podmiotów podobnych;

- po trzecie, argumenty te muszą pozostawać w jakimś związku z innymi wartościami, zasadami czy normami konstytucyjnymi, uzasadniającymi odmienne traktowanie podmiotów podobnych (np. orzeczenie z 23 października 1995 r., K 4/95, OTK w 1995 r., cz. II, s. 93). Jak już wspomniano, jedną z takich zasad konstytucyjnych jest zasada sprawiedliwości społecznej (art. 1 przepisów konstytucyjnych). Różnicowanie sytuacji prawnej podmiotów podobnych ma więc znacznie większe szanse uznania za zgodne z konstytucją, jeżeli pozostaje w zgodzie z zasadami sprawiedliwości społecznej lub służy urzeczywistnieniu tych zasad. Zostaje ono natomiast uznane za niekonstytucyjną dyskryminację (uprzywilejowanie), jeżeli nie znajduje podtrzymania w zasadzie sprawiedliwości społecznej. W tym sensie zasady równości wobec prawa i sprawiedliwości społecznej w znacznym stopniu nakładają się na siebie".

Minister Sprawiedliwości w odpowiedzi z dnia 20 września 2013 r. wyjaśnił ${ }^{37}$, że brak jest przesłanek do podjęcia inicjatywy ustawodawczej mającej na celu rozszerzenie kręgu podmiotów mogących ubiegać się o pomoc w postaci ryczałtu z Funduszu Aktywizacji Zawodowej Skazanych oraz Rozwoju Przywięziennych Zakładów Pracy. Fundusz w swoim działaniu ma kierować się przede wszystkim dobrem osób pozbawionych wolności. Rekompensata finansowa dla podmiotów zatrudniających skazanych jest jedynie pewną zachętą do zatrudniania tej konkretnej kategorii osób, które znajdują się w niewątpliwie niełatwej sytuacji na rynku pracy. Zgodnie z ustawą o zatrudnianiu osób pozbawionych wolności, do otrzymania ryczałtu ze środków Funduszu uprawnieni są przedsiębiorcy zatrudniający osoby pozbawione wolności. Ograniczenie dla podmiotów niebędących przedsiębiorcą zastosowane jest wyłącznie do jednej z trzech form pomocy oferowanych w ramach Funduszu, gdyż inne formy takiej pomocy, tj. pożyczka oraz dotacje mogą być przyznane tym podmiotom. Według Ministra Sprawiedliwości dopatrywanie się dyskryminacji $\mathrm{w}$ obowiązującym rozwiązaniu, nie jest trafne. Żaden $\mathrm{z}$ podmiotów zatrudniających osoby pozbawione wolności nie jest, co do zasady, wykluczony z otrzymania

\footnotetext{
${ }^{37}$ https://www.rpo.gov.pl/sites/default/files/Odpowiedz\%20MS\%20z\%20dnia\%2020.09.2013\%20r.pdf [dostęp: 3 października 2015 r.].
} 
pomocy z Funduszu. Fundacje mogą prowadzić działalność gospodarczą w rozmiarach służących realizacji ich celów. Zatem tylko od woli fundacji zależy, czy podejmując działalność gospodarczą uzyska status przedsiębiorcy oraz tym samym możliwość ubiegania się o rekompensatę w postaci ryczałtu z Funduszu. Fundacje, jak i większość pozostałych podmiotów zatrudniających osoby pozbawione wolności niebędących przedsiębiorcami, korzystają z nieodpłatnej pracy skazanych, co stanowić może, jak w przypadku ryczałtu dla przedsiębiorców, rekompensatę za zwiększone koszty zatrudnienia osób pozbawionych wolności.

Nie podzielając w pełni przedstawionej argumentacji, Rzecznik zwróciła się do organizacji pozarządowych, zainteresowanych tym zagadnieniem, o zajęcie stanowiska. Jedna z organizacji ${ }^{38}$ wskazała, iż ryczałt jest bezzwrotną formą pomocy i przysługuje raz na trzy miesiące, zaś pożyczka jest zwrotną formą pomocy, przysługującą po okresie rocznego zatrudnienia osoby pozbawionej wolność. Ponadto, o dotację można ubiegać się po dwuletnim okresie zatrudnienia w.w. osób. Dla większości organizacji pozarządowych są to warunki, którym nie mogą sprostać. Rzecznik po analizie orzecznictwa Trybunału doszedł jednak do przekonania, iż nie jest w stanie dowieść naruszenia przepisów Konstytucji RP i wobec nieprzychylnego stanowiska Ministra, odłożył sprawę ad acta.

c) Wystąpienie generalne $\mathrm{z}$ dnia 3 lipca $2014 \mathrm{r}^{39}$

W działalności Rzecznika Praw Obywatelskich ujawnił się także problem naprzemiennego zatrudnienia odpłatnego i nieodpłatnego skazanych, a został on dostrzeżony podczas badania zarzutów dotyczących warunków i zasad zatrudniania oraz wynagradzania za pracę osadzonych w jednostkach penitencjarnych.

Wątpliwości Rzecznika budziła praktyka polegająca na organizowaniu zatrudnienia osadzonych $\mathrm{w}$ drodze przemiennego zatrudnienia odpłatnego i nieodpłatnego. Zgodnie $\mathrm{z}$ tym systemem osadzony pracuje nieodpłatnie przez jeden miesiąc, natomiast w drugim miesiącu wykonuje tę samą pracę, w tym samym wymiarze godzin, otrzymując za nią wynagrodzenie. Rzecznik odwołała się w wystąpieniu do wyroku $^{40}$ Trybunału Konstytucyjnego, w którym Trybunał uznał za niezgodny z Konstytucją przepis k.k.w., pozwalający na zatrudnianie skazanych w pełnym wymiarze czasu pracy za wynagrodzeniem w wysokości połowy minimalnego

\footnotetext{
${ }^{38} \mathrm{https} / /$ www.rpo.gov.pl/sites/default/files/Pisma\%20od\%20Stowarzyszenia\%20Interwencji\%20Prawnej\%20i \%20Fundacji\%20Pomoc\%20Potrzebuj\%C4\%85cym.pdf [dostęp: 3 października 2015 r.].

${ }^{39}$ II.517.1812.2014 http://www.sprawy-generalne.brpo.gov.pl/pdf/2014/7/II.517.1812.2014/159012.pdf [dostęp: 3 października 2015 r.].

${ }^{40}$ Wyrok TK z 23 lutego 2010 r., sygn. akt P 20/09.
} 
wynagrodzenia pracowników. Trybunał wskazał, że prawo więźniów do sprawiedliwego wynagradzania za pracę wynika wprost z konstytucyjnego nakazu humanitarnego traktowania osób pozbawionych wolności oraz zakazu stosowania tortur, okrutnego, nieludzkiego lub poniżającego traktowania i karania. Trybunał stanął na stanowisku, że trudność zapewnienia więźniom pracy za wynagrodzeniem według zasad wynagrodzenia pracowników, nie może uzasadniać odstąpienia od zagwarantowania stawki wynagrodzenia minimalnego zatrudnionym odpłatnie więźniom. W ocenie Rzecznika, stosowane zasady zatrudniania osadzonych, naruszają prawo tych osób do sprawiedliwego wynagrodzenia za pracę, zmierzając jednocześnie do ominięcia uregulowań prawnych wprowadzonych do Kodeksu karnego wykonawczego w efekcie wyroku Trybunału Konstytucyjnego. Rzecznik zwróciła się do Dyrektora Generalnego Służby Więziennej o przedstawienie stanowiska w sprawie.

Dyrektor Generalny Służby Więziennej poinformował ${ }^{41}$, że generalną zasadą przyjętą w k.k.w. jest odpłatność pracy skazanego. Wynagrodzenie przysługujące skazanemu zatrudnionemu w pełnym wymiarze czasu pracy ustala się w sposób zapewniający osiągnięcie co najmniej minimalnego wynagrodzenia. Natomiast za prace porządkowe i pomocnicze wykonywane na rzecz jednostek organizacyjnych Służby Więziennej w wymiarze nieprzekraczającym 90 godzin, wynagrodzenie nie przysługuje. W celu objęcia zatrudnieniem odpłatnym jak największej liczby osadzonych, osadzeni zatrudniani są $\mathrm{w}$ niepełnym wymiarze czasu pracy. Pomimo orzeczenia Trybunału Konstytucyjnego, zmieniającego zasady wynagradzania skazanych za pracę, wysokość środków budżetowych przeznaczonych na płace skazanych zatrudnionych przy pracach porządkowych i pomocniczych wykonywanych na rzecz jednostek organizacyjnych Służby Więziennej nie uległa odpowiedniemu zwiększeniu. Skazany początkowo zatrudniany jest nieodpłatnie, a następnie, jeżeli jest wolny etat, skazany przenoszony jest do zatrudnienia odpłatnego. W okresie zatrudnienia nieodpłatnego sprawdzane są jego kwalifikacje, umiejętności oraz motywacja do wykonywania pracy. Natomiast praktyka przemiennego tj. odpłatnego i nieodpłatnego zatrudnienia nie powinna mieć miejsca.

Jednocześnie Dyrektor Generalny Służby Więziennej wskazał, iż w celu wyeliminowania takich praktyk w przyszłości, kwestie te zostaną omówione na

\footnotetext{
${ }^{41}$ Pismo z 28 lipca 2014 r. http://www.sprawy-generalne.brpo.gov.pl/szczegoly.php?pismo=159012 [dostęp: 3 października 2015 r.].
} 
odprawach służbowych z funkcjonariuszami i pracownikami realizującymi w jednostkach penitencjarnych zadania z zakresu zatrudnienia osadzonych.

d) Sprawa indywidualna

Do Rzecznika zwróciła się Pani Małgorzata S., odbywająca karę pozbawienia wolności w Zakładzie Karnym Nr 1 w Ł. Żaliła się ona na decyzję w przedmiocie wycofania z zatrudnienia ${ }^{42}$.

W toku podjętych czynności ustalono, że podczas odbywania kary pozbawienia wolności Pani Małgorzata S. od dnia 4 sierpnia 2010 r. wykonywała pracę na rzecz firmy prowadzącej działalność w Ł. Z zatrudnienia została wycofana z dniem 13 kwietnia 2011 r. na wniosek pracodawcy, z powodu odmowy wykonywania pracy.

$\mathrm{Z}$ zebranych $\mathrm{w}$ toku badania sprawy informacji wynika, że osadzona odmówiła wykonywania pracy z powodu zbyt niskiego wynagrodzenia, jakie otrzymała za miesiąc marzec 2011 r. Jak ustalono, w związku z wejściem w życie z dniem 8 marca 2011 r. nowelizacji przepisu art. $123 \S 2$ k.k.w., który zobowiązuje do ustalenia wynagrodzenia przysługującego skazanemu zatrudnionemu w pełnym wymiarze czasu pracy na poziomie co najmniej minimalnego wynagrodzenia pracowników, pracodawca zmienił zasady wynagradzania skazanych za pracę, wprowadzając, zamiast dotychczasowej stawki godzinowej, stawkę akordową. Wynagrodzenie osiągnięte przez osadzoną w miesiącu marcu zostało rozliczone odrębnie za okres 1-7 marca oraz 8-31 marca 2011 r. W wyniku wprowadzonych zmian za pierwszy okres $(7 \mathrm{dni})$ otrzymała ona wynagrodzenie brutto w wysokości 154,60 zł, za drugi natomiast (24 dni) - 135,83 zł (w miesiącu lutym wynagrodzenie osadzonej brutto wyniosło 600,07 zł).

Ustalenia dokonane $\mathrm{w}$ toku postępowania wyjaśniającego wykazały, że zgodnie z umową zawartą pomiędzy Zakładem Karnym $\mathrm{Nr} 1 \mathrm{w}$ Ł. i firmą zatrudniającą Panią Małgorzatę S., wyłącznie pracodawca określa stawkę wynagrodzenia, o wprowadzonych zmianach jedynie informując administrację zakładu karnego.

Okręgowy Inspektorat Pracy w Ł., do którego zwrócił się Rzecznik, uchylił się od badania tej sprawy, uznając, że ponieważ Pani Małgorzata S. była zatrudniona na podstawie skierowania do pracy przez dyrektora zakładu karnego, jej roszczenie w przedmiocie wynagrodzenia nie jest roszczeniem ze stosunku pracy i z tego względu nie podlega kontroli Państwowej Inspekcji Pracy. W piśmie stwierdzono natomiast, że postępowanie, jakie zastosowano wobec Pani Małgorzaty S., nie byłoby dopuszczalne w stosunku pracy.

\footnotetext{
${ }^{42}$ https://www.rpo.gov.pl/pliki/13527103260.pdf s. 221-222. [dostęp: 3 października 2015 r.].
} 
Rzecznik stanął na stanowisku, że sposób wynagradzania osób zatrudnionych na podstawie skierowania do pracy, nie może być determinowany wyłącznie względami ekonomicznymi pracodawcy, a dokonywanie zmian w zasadach wynagradzania nie powinno następować $\mathrm{w}$ sposób mniej korzystny, niż to wynika z Kodeksu pracy w przypadku pracowników. Dyrektor zakładu karnego, będący stroną zawierającą umowę z pracodawcą, winien natomiast dbać o interes skazanych zatrudnionych i nie dopuszczać do stosowania niekorzystnych dla pracowników rozwiązań. W związku z powyższym Rzecznik zwrócił się w tej sprawie do Centralnego Zarządu Służby Więziennej.

W udzielonej odpowiedzi Centralny Zarząd Służby Więziennej podzielił pogląd RPO i stwierdził, że w przedmiotowej sprawie administracja Zakładu Karnego Nr 1 w Ł. nie zachowała należytej staranności przy zmianie zasad wynagradzania skazanych. Podjęcie działań zmierzających do zmiany niekorzystnych zasad przyjętych w umowie z pracodawcą nie było jednak możliwe, ponieważ z dniem 1 lipca 2011 r. firma rozwiązała umowę z Dyrektorem Zakładu Karnego Nr 1 w Ł.

e) Wystąpienie generalne $\mathrm{z}$ dnia 10 lipca $2015 \mathrm{r}$.

W kolejnym wystąpieniu do Ministra Sprawiedliwości z dnia 10 lipca 2015 r. Rzecznik Praw Obywatelskich wskazała, że ciągle otrzymuje wnioski od skazanych niejednokrotnie posiadających zobowiązania alimentacyjne - w których podnoszą oni brak możliwości wykonywania odpłatnej pracy w czasie pobytu w zakładzie karnym.

Rzecznik wskazała na dane statystyczne, które jednoznacznie wskazują na załamanie się zatrudnienia odpłatnego od 2011 r., tj. od daty wprowadzenia w życie nowej treści art. $123 \S 2$ k.k.w. RPO podnosi, że zmiana regulacji doprowadziła do spadku liczby kontrahentów (w 2008 r. było ich 6858, w 2013 r. już tylko 1785). Analogiczna tendencja dotyczyła liczby przywięziennych zakładów pracy, zatrudniających skazanych.

Rzecznik wskazała również, że wprowadzenie dodatkowych instrumentów zachęcających poszczególne podmioty do zatrudnienia skazanych (z tytułu kosztów zatrudnienia, przedsiębiorca zatrudniający osoby pozbawione wolności otrzymuje ryczałt w wysokości $20 \%$ wartości wynagrodzeń przysługujących zatrudnionym osobom oraz po spełnieniu określonych warunków może ubiegać się o dotację lub pożyczkę) nie przyniosły oczekiwanego rezultatu.

Według RPO, ustawodawca, dokonując dostosowania systemu prawa do treści wyroku Trybunału Konstytucyjnego z dnia 23 lutego 2010 r., uznał, że nie ma możliwości wywiedzenia z uzasadnienia wyroku Trybunału podstawy do zróżnicowania poziomu wynagrodzenia dla skazanych, tymczasem w uzasadnieniu tego wyroku TK zaznaczył, iż 
„konstytucja nie wymaga, aby minimalne wynagrodzenie za pracę zostało ustalone na jednakowym poziomie dla wszystkich pracowników. Konstytucyjna zasada równości nie wyklucza zróżnicowania minimalnego wynagrodzenia za pracę, na przykład na podstawie kryteriów branżowych czy terytorialnych, czy też w zależności od długości okresu zatrudnienia, jeżeli tylko ustanowione różnicowania będą miały charakter usprawiedliwiony i spełnią przedstawione wyżej warunki dopuszczalności różnicowań. Dotyczy to również minimalnego wynagrodzenia za pracę osób skazanych".

W tej sytuacji Rzecznikowi wydaje się, że ustawodawca mógł rozważyć również inne rozwiązania prawne niż przyjęcie, że skazany nie może otrzymać niższego wynagrodzenia za pracę niż minimalne wynagrodzenie, przy jednoczesnej zgodności przepisów z Konstytucją RP i wyrokiem Trybunału. W wystąpieniu RPO zaznaczyła również, że ma „świadomość, że teza ta nie jest oczywista po analizie treści powołanego wyroku, niemniej jednak warto w moim przekonaniu pochylić się nad tym zagadnieniem raz jeszcze, biorąc pod uwagę wartość, jaką jest praca dla osób pozbawionych wolności, a także skutki ekonomiczne i społeczne".

Konkludując, Rzecznik zwróciła się do Ministra Sprawiedliwości o przeanalizowanie przedstawionego zagadnienia i rozważenie możliwości podjęcia inicjatywy legislacyjnej, mającej na celu doprowadzenie do zwiększenia poziomu odpłatnego zatrudniania skazanych.

W odpowiedzi z dnia 20 sierpnia 2015 r. Minister Sprawiedliwości podniósł, że na ryzyko spadku zatrudnienia wskazywał w swoim orzeczeniu sam Trybunał, nadto, że w celu przeciwdziałania temu zjawisku Służba Więzienna podjęła określone działania, m.in. poprzez promocję zatrudnienia skazanych oraz wprowadzenie możliwości skorzystania przez przedsiębiorców z Funduszu Aktywizacji Zawodowej Skazanych oraz Rozwoju Przywięziennych Zakładów Pracy. Według Ministra „stworzenie dla przedsiębiorców systemu zachęt i udogodnień nie spowodowało na razie znacznego wzrostu poziomu odpłatnego zatrudnienia skazanych”, jednakże „działania te mają charakter długofalowy i ich ewentualną skuteczność będzie można zweryfikować dopiero po upływie dłuższego okresu”. Według danych statystycznych podanych w odpowiedzi, widoczna jest pewna poprawa, jeśli chodzi o liczbę skazanych zatrudnionych oraz o liczbę przedsiębiorców korzystających z funduszu pomiędzy rokiem 2013 i 2014 (odpowiednio 9184 - 10.028 i 1785 - 1984).

W kwestii zróżnicowania wynagrodzenia minimalnego skazanych Minister Sprawiedliwości wskazuje, że „wydaje się, że rzeczywiście jest ono możliwe biorąc pod uwagę kryteria branżowe lub terytorialne, ale nadzwyczaj wątpliwym jest w świetle treści wskazanego wyroku Trybunału Konstytucyjnego, by mogłoby ono być ustalone poniżej 
ustawowej wartości minimalnego wynagrodzenia, ustalanego w myśl art. 17 ustawy z dnia 10 października 2002 r. o minimalnym wynagrodzeniu za pracę (Dz. U. Nr 200, poz. 1679 z późn. zm.)”. Kończąc odpowiedź, Minister wskazuje, że „celowym byłoby powołanie międzyresortowego zespołu z udziałem nie tylko przedstawicieli resortu sprawiedliwości i Służby Więziennej, ale również Ministerstwa Pracy i Polityki Społecznej oraz Ministerstwa Gospodarki, dla wypracowania planu działań mających na celu zwiększenie aktywizacji zawodowej osób skazanych”.

\section{Podsumowanie}

Zaprezentowane najważniejsze działania Rzecznika Praw Obywatelskich (w porządku chronologicznym) w kwestii zatrudnienia skazanych pokazują, iż to zagadnienie jest niezmiernie ważne w działalności RPO. Aktywność ta ma miejsce na różnych polach, tak poprzez rozpoznawanie spraw indywidualnych, jak i poprzez wystąpienia o charakterze generalnym, a także poprzez działania „miękkie”. W niniejszej publikacji wskazano na wszystkie te działania, które mają jeden cel, tj. zapewnienie jak najszerszego zatrudnienia wśród osób pozbawionych wolności, przy jednoczesnym zapewnieniu respektowania ich praw do godziwego wynagrodzenia. Wydaje się, iż obecna regulacja prawna co do wynagrodzenia skazanych, będzie podlegała dalszym zmianom, w celu uelastycznienia i zwiększenia tego zatrudnienia. Trybunał Konstytucyjny nie wykluczył w swoim orzeczeniu możliwości różnicowania wynagrodzenia osób pozbawionych wolności względem innych pracowników. Również sam ustawodawca w ustawie o płacy minimalnej wskazuje sytuację, w której można wypłacić określoną procentowo kwotę wynagrodzenia minimalnego. Jak wskazano w doktrynie, nie stoją temu na przeszkodzie również regulacje międzynarodowe. Trzeba jednak zauważyć, iż ustawodawca, dokonując zmian w kwestii wynagradzania skazanych, powinien pochylić się nad tym zagadnieniem, biorąc pod uwagę zawarty w art. $121 \S 2$ k.k.w. podział form zatrudnienia.

\section{Bibliografia:}

\section{Literatura}

Bramska M., Zatrudnienie (w:) Stan i węzłowe problemy polskiego więziennictwa, red. J. Malec, RPO-Mat. Nr 28, Warszawa 1995Bulenda T., Musidłowski R., Zagórski J., Konstytucyjne wolności i prawa socjalne osób uwięzionych i ich urzeczywistnianie (w:) Godność czlowieka a prawa ekonomiczne i socjalne. Księga jubileuszowa wydana $w$ piętnasta rocznice ustanowienia Rzecznika Praw Obywatelskich, Warszawa 2003

Garlicki L., Komentarz do art. 32 Konstytucji. Komentarz. T. III, Wydawnictwo Sejmowe, Warszawa 2003 
Kalisz T., Kwieciński A., Zmiany w zakresie odpłatności za pracę skazanych odbywajacych kare pozbawienia wolności. Rozważania na tle orzecznictwa Trybunału Konstytucyjnego (w:) Zmiany w prawie karnym wykonawczym w latach 2009-2014, red. A. Kwieciński,Warszawa 2014

Majewski W., Migal Z., Zatrudnienie więźniów (w:) Księga jubileuszowa więziennictwa polskiego 1989-2009, red. T. Szymanowski, J. Cegielska, J. Czołgoszewski, S. Lelental, J. Pomiankiewicz, Warszawa 2009

Odrowąż-Sypniewski W., Opinia w sprawiezgodności z Konstytucją RP projektowanego brzmienia art. 123 \$2 Kodeksu karnego wykonawczego (z dnia 6 marca 2003 r.)

Płatek M., Opina prawna do projektu ustawy o zmianie ustawy - kodeks karny wykonawczy oraz niektórych innych ustaw (druk nr 389) - projekt poselski (z dnia 14 maja 2002 r.)

Postulski K., Komentarz do art. 121 kodeksu karnego wykonawczego, LEX/el 2014

Sieradzka M., Komentarz do art. 4 ustawy o swobodzie działalności gospodarczej, LEX/el. 2012

Wójcik-Adamska K., Zatrudniony więzień bez emerytury, http://www4.rp.pl/artykul/706328Wiezniowie-zatrudnieni-ale-bez-emerytury.html

Zdyb M., Prawo działalności gospodarczej. Komentarz, Warszawa 2000

\section{Netografia}

https://www.rpo.gov.pl/pl/krajowy-mechanizm-prewencji

http://www.sprawy-generalne.brpo.gov.pl/szczegoly.php?pismo=264050

https://www.rpo.gov.pl/sites/default/files/Debata_Zatrudnienie_osob_skazanych_z_dnia_13-09-

2012_r_cz.\%20I_13-09-2012\%20czI.mp3

https://www.rpo.gov.pl/sites/default/files/Debata_Zatrudnienie_osob_skazanych_z_dnia_13-09-

2012_r_cz_II.mp3

https://www.rpo.gov.pl/pl/content/krajowy-mechanizm-prewencji-zorganizowa\%C5\%82-w-biurzerzecznika-praw-obywatelskich-debat $\% \mathrm{C} 4 \% 99$

http://www.sprawy-generalne.brpo.gov.pl/szczegoly.php?pismo=1476712

https://www.rpo.gov.pl/sites/default/files/Wyst\%C4\%85pienie\%20RPO-695870-VII-

$12 \% 20 \mathrm{do} \% 20$ Ministra\%20Sprawiedliwo\%C5\%9Bci\%20z\%20dnia\%2019.08.2013\%20r.pdf

https://www.rpo.gov.pl/sites/default/files/Odpowiedz\%20MS\%20z\%20dnia\%2020.09.2013\%20r.pdf

https://www.rpo.gov.pl/sites/default/files/Pisma\%20od\%20Stowarzyszenia\%20Interwencji\%20Prawn ej\%20i\%20Fundacji\%20Pomoc\%20Potrzebuj\%C4\%85cym.pdf

http://www.sprawy-generalne.brpo.gov.pl/pdf/2014/7/II.517.1812.2014/159012.pdf

http://www.sprawy-generalne.brpo.gov.pl/szczegoly.php?pismo=159012

https://www.rpo.gov.pl/pliki/13527103260.pdf 